\title{
Phosphogypsum Recycling: A Review of Environmental Issues, Current Trends, and Prospects
}

\author{
Yelizaveta Chernysh ${ }^{1, *(\mathbb{D}, \text { Olena Yakhnenko }}{ }^{1}$, Viktoriia Chubur ${ }^{1}$ and Hynek Roubík ${ }^{2, *(1)}$ \\ 1 Department of Ecology and Environmental Protection Technologies, Sumy State University, 40007 Sumy, \\ Ukraine; o.jakhnenko@ecolog.sumdu.edu.ua (O.Y.); v.chubur@ecolog.sumdu.edu.ua (V.C.) \\ 2 Department of Sustainable Technologies, Faculty of Tropical AgriSciences, Czech University of Life Sciences \\ Prague, 16500 Prague, Czech Republic \\ * Correspondence: e.chernish@ssu.edu.ua (Y.C.); roubik@ftz.czu.cz (H.R.); \\ Tel.: +380-542-331-205 (Y.C.); +420-22438-2487 (H.R.)
}

check for updates

Citation: Chernysh, Y.; Yakhnenko,

O.; Chubur, V.; Roubík, H.

Phosphogypsum Recycling: A Review of Environmental Issues,

Current Trends, and Prospects. Appl.

Sci. 2021, 11, 1575. https://doi.org/

10.3390/app11041575

Academic Editor: María

Ángeles Martín-Lara

Received: 29 December 2020

Accepted: 5 February 2021

Published: 9 February 2021

Publisher's Note: MDPI stays neutral with regard to jurisdictional claims in published maps and institutional affiliations.

Copyright: (c) 2021 by the authors. Licensee MDPI, Basel, Switzerland. This article is an open access article distributed under the terms and conditions of the Creative Commons Attribution (CC BY) license (https:// creativecommons.org/licenses/by/ $4.0 /)$.
Abstract: The problem of recycling and storage of phosphogypsum is topical for many countries around the world, as it is associated with environmental problems of pollution of water bodies, land, and atmosphere. Therefore, this paper analyzes the directions of phosphogypsum recycling and possible alternatives to its use. The main disadvantages of the existing methods of phosphogypsum processing were identified and trends in this waste management were also considered. Through the VOSviewer programme, a visualization of cluster interconnections was carried out in research publications of various fields of phosphogypsum utilization. Five clusters were formed: a red cluster-phosphogypsum recycling in the construction industry; green cluster-radiation pollution problem of phosphogypsum and phosphate fertilizers; yellow cluster-monitoring migration of phosphogypsum components in the ecosystem, with the mobile forms of heavy metals and their inflow into aquifers from phosphogypsum dumps; blue cluster-use of phosphogypsum in agriculture as an ameliorant and a component of fertilizer; and a purple cluster-the impact of phosphogypsum on microorganisms, particularly in bioremediation processes. Under the proposed integrated biochemical approach, the use of various bioprocesses of phosphogypsum recovery from waste dumps and implementation of new biotechnological solutions for processing phosphorus raw materials are presented.

Keywords: phosphogypsum; recycling; processing methods; management; cluster visualization; biochemical approach

\section{Introduction}

Phosphogypsum is an almost unused by-product of phosphate fertilizer production, which includes several valuable components-calcium sulphates and rare-earth elements such as silicon, iron, titanium, magnesium, aluminum, and manganese, as well as toxic elements such as heavy metals and others. Open storage of phosphogypsum in waste dumps is common. Phosphogypsum dumps are located in open areas in close proximity to the enterprise, natural complexes, and even settlements, and occupy vast territories. Transportation of phosphogypsum and storage in dumps entails investment and operating costs. For example, up to $10 \%$ of the prime cost of phosphoric acid refers to the costs for transportation and storage of phosphogypsum [1]. Waste dumps of industrial processing of natural raw materials are continually being replenished and are taking on scales that threaten the sustainable function of biocenoses. The current growth rate of phosphogypsum is estimated at 200 million tons per year, with a mass utilization rate of $10-15 \%$ according to the most optimistic forecasts.

The problem of phosphogypsum utilization and storage is essential for many countries as it has environmental issues (pollution of water, land, and atmosphere). Currently, over 55 million tons of phosphogypsum are accumulated in Ukraine (Armyansk, Sumy, Rivne, 
and other cities), occupying large areas that may otherwise be suitable for agricultural activities. Specifically, over 15 million tons of phosphogypsum are accumulated in the Sumy region alone. Years of waste storage from the production of mineral fertilizers in Ukraine has resulted in the formation of anthropogenic phosphogypsum deposits, which amount to 15.2 million tonnes in Rivne region [2], and 421.11 tons of phosphogypsum has accumulated in Vinnitsa region of Ukraine [3]. The U.S. Environmental Protection Agency prohibits the use of phosphogypsum because of its radioactivity. For example, phosphogypsum from Central Florida has an average of $26 \mathrm{pCi} / \mathrm{g}$ radium, and that from North Florida has $10 \mathrm{pCi} / \mathrm{g}$ radium. An exception is made for phosphogypsum with an average concentration of less than $10 \mathrm{pCi} / \mathrm{g}$ radium, which can be used as an agricultural amendment, but not for other purposes [4]. It is important to note that the content of radioactive elements in phosphogypsum is related to the raw material used in industrial processes.

China also has significant production of phosphogypsum, and the five largest provinces in terms of production are Hubei, Yunnan, Guizhou, Sichuan, and Anhui [5]; hence, they these also have large storage sites. Poland also has significant phosphogypsum storage facilities. More than 5 million tons of apatite phosphogypsum has been accumulated in the waste dumps of the Wizowski Chemical Plant (Poland). These wastes contain rare-earth elements, which are listed as "critical" raw materials in the European Union (EU) [6]. In Russia, there is over 500 million tons of phosphogypsum accumulation at existing ammonium phosphorus production facilities, which accumulated over all the years of their operation [7].

The negative environmental impact of phosphogypsum dumps can be manifested in the contamination of groundwater and surface water, soil, and vegetation cover by substances seeping through the protective screen, as a result of their evaporation and washout from the dump by atmospheric precipitation as well as airborne emission under the influence of weathering and dusting. The dump is a source of hydrodynamic impact on the environment, causing changes in groundwater levels, which leads to negative phenomena in the residential area, such as alienation and pollution of land areas and the transformation of the natural landscape. The large dumping of phosphate fertilizer production waste has serious consequences for the marine environment, which was studied in [8]. For example, the dumping of phosphogypsum affects the phosphorus cycle with a high content of authigenic phosphorus, especially in the Gulf of Gabes [8]. As studied in [9], phosphogypsum consisting of calcium sulphate and other complementary salts enters seawater as particles. After the particles dissolve, the concentration of heavy metals may affect near the release point. This is a significant environmental problem, especially in the Atlantic Ocean around two locations: Safi and Yorf Lasfar, where the Moroccan phosphate industry emits large quantities of this waste [9]. A study [10] characterized the formed layers of foam from the discharge of phosphogypsum into coastal waters, which can float on the surface and be passively transported to remote areas to understand their role in the behavior of pollutants in the marine environment [10].

Overview of Studies on the Environmental Impact of Phosphogypsum Accumulation and Storage

These specific conditions should be considered when choosing a method for removing and storing phosphogypsum in dumps:

- the production capacity;

- the amount of phosphogypsum that must be removed;

- the remoteness of the extraction components from the phosphogypsum storage site;

- the availability of storage land (unsuitable for other uses);

- the dump topography;

- the climatic conditions;

- the geological and hydrogeological conditions at the phosphogypsum storage site.

To create dumps, it is necessary to allocate large areas. Often, these areas exceed the size of industrial sites of the production itself. Thus, $\mathrm{P}_{2} \mathrm{O}_{5}$ production requires an area of 
$1.2 \times 1.2 \mathrm{~km}$ with a blade height of $15 \mathrm{~m}$ to store phosphogypsum for 20 years [11]. Storage of phosphogypsum in waste heaps poses an environmental hazard, even if the facility is operated correctly. The problem of the utilization and storage of phosphogypsum is relevant for many countries around the world.

There are known cases of soil, natural water pollution, and contamination of plant products due to interaction with phosphogypsum in different countries, such as Brazil, China, Greece, Jordan, Kazakhstan, Poland, Russia, Spain, Turkey, and United States of America [12-14].

When large areas are allocated for phosphogypsum storage sites, the natural landscape is transformed, the functioning of edaphotopes is disturbed, and the aesthetic appearance of the surrounding landscape is affected. This results in phosphogypsum storages being complex sources of pollution and environment deformation; they disturb the terrain, interrupt or change the natural flow of intrasoil migration of substance, pollute the landscape with technogenic substances, change the nature of surface air flows, and affect the humidity index of the site. The dump is a source of hydrodynamic impact on the environment, causes changes in groundwater levels, and leads to negative effects in the residential area. In addition, dry phosphogypsum dumps have a potential risk of erosion because of the content of more than $70 \%$ of particles with a diameter of less than $0.14 \mathrm{~mm}$ in the dump surface layer $[11,15]$.

In the study done by Torres-Sánchez et al. (2020), hydrogen fluoride (HF) concentrations in an urban area (Huelva, southwest Spain) were associated with a nearby large phosphogypsum deposit. The geochemical anomaly of HF was discovered with average concentrations of up to $19.1 \mu \mathrm{g} / \mathrm{m}^{3}$ and concentrations of up to $1.6 \mu \mathrm{g} / \mathrm{m}^{3}$ were found in the nearest urban area. Concentrations were associated directly with the emission of HF from the phosphogypsum accumulation site [16].

The existing modern technologies of fertilizer production do not pay enough attention to the purification of raw materials from impurity elements. Therefore, the solid waste contains fluorine, rare-earth metals, arsenic, strontium, heavy metals (cadmium, lead, vanadium, and others), and radioactive elements. Thus, uranium in the structural lattice and isomorphously replaces calcium in phosphorites, which are sedimentary rocks. Hence, the content of uranium in phosphorites depends on the geochemical conditions of their origin [17].

During dry storage (without pre-neutralization), an average of $0.1 \%$ fluorine is released into the gas phase in terms of dry matter contained in phosphogypsum. Dust rising above the dumps contains an average of up to $10 \mathrm{~g}$ of fluorine per 1 ton of phosphogypsum (dust distribution radius is up to $1.5 \mathrm{~km}$ ) [17]. Fluoride compounds are highly toxic to the flora. The harmless concentration of fluorine is $0.00017-0.00023 \mathrm{mg} / \mathrm{m}^{3}$, according to the study by Sharipov (2014), which is much lower than the maximum permissible concentration (MPC) and amounts to $0.005 \mathrm{mg} / \mathrm{m}^{3}$ [18]. Leaves of fruit trees get brown and fall off; fruits develop poorly under conditions of fluorine content in the atmosphere of $0.003-0.01 \%$. A weakening of the growth of pine plantations up to $50 \mathrm{~km}$ away from the source of fluoride gases has been observed [19].

The impact of waste dumps on water pollution is caused by the leaching of phosphogypsum components during storage in open areas. The formation of runoff at the dry phosphogypsum dumps is associated with precipitation and with the loss of water under hydraulic forces [20].

Wastewater generated on the slopes of the dumps during precipitation contains up to $3.4 \mathrm{~g} / \mathrm{L} \mathrm{P}_{2} \mathrm{O}_{5}$; this is hundreds of times higher than the natural content of phosphorus anion in the surface waters of humid zones. Approximately $10 \%$ of fluorine is washed out by precipitation [17]. Wet, freshly formed phosphogypsum has a low $\mathrm{pH}$ (because of the presence of water-soluble fluorine compounds: $\mathrm{H}_{2} \mathrm{SiF}_{6}, \mathrm{Na}_{2} \mathrm{SiF}_{6}, \mathrm{~K}_{2} \mathrm{SiF}_{6}$, and $\mathrm{HF}$ ), traces of unwashed phosphoric and sulfuric acid, and phosphoric salts, and shows high corrosive activity.

The issue of phosphogypsum disposal is still very relevant, for the following reasons: 
- The storage of phosphogypsum on the territory of the enterprise deteriorates the sanitary condition of the site and the adjacent territory;

- The transportation and storage of phosphogypsum in dumps are connected with rather high costs-about $18 \%$ of the cost of construction of phosphoric acid production itselfand they significantly increase during the transition to more reliable hydrotransport for phosphogypsum. Operating costs are approximately $12 \%$ of the cost of raw material processing [21];

- The need to alienate large areas to create dumps. These areas may exceed the size of industrial sites of enterprises;

- The exploitation of the dumps poses a potential threat to the environment and residential landscapes adjacent to the dump.

It is noteworthy to mention that phosphogypsum valorization has still its limitations; particularly, because of the high cost of its removal, new alternatives must be found to reduce the use of land for phosphogypsum storage [22].

This paper aims to analyze the directions of phosphogypsum recycling (a by-product of phosphate fertilizer production) and possible alternatives to its use.

To achieve this aim, the following tasks were set:

- The analysis of phosphogypsum processing methods and highlighting key trends;

- The visualization of the network system by phosphogypsum research areas and consideration of alternative solutions for the disposal of phosphogypsum.

\section{Analysis of Trends in Phosphogypsum Use}

Considering the quantities of formed and produced phosphogypsum, the actual problem is not only the phosphogypsum removal, transportation, and storage in waste dumps and sludge collectors, but also its utilization with already developed methods and the development of new methods and more possibilities for its use.

Based on the number of publications (Figure 1), the interest in phosphogypsum as a source of secondary raw materials has significantly increased over the past decade. Initially, phosphogypsum was considered mainly as a component for construction, cement, road-building, and agricultural industries. However, over the last 10-20 years, given the increasing anthropogenic pressure on the environment and the resulting shortage of natural sources of raw materials, the focus has shifted. Phosphogypsum, which has many useful elements, is thus being considered as a source of calcium, phosphorus, rare-earth elements, and trace elements, among other, as well as a mineral resource in technological processes of environmental protection.

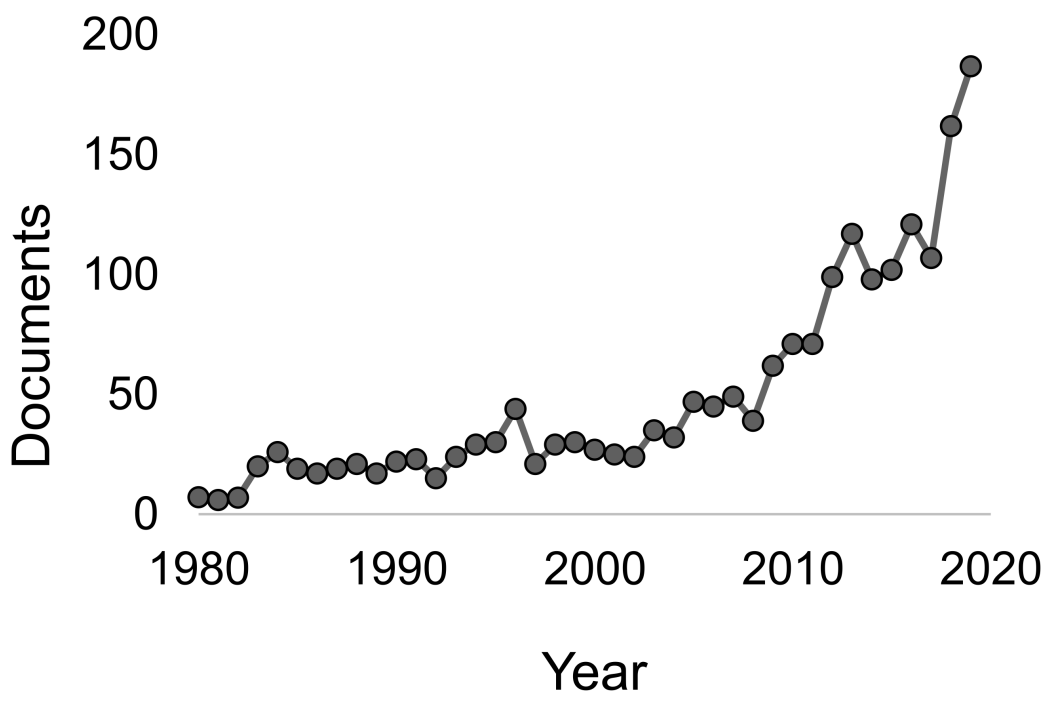

Figure 1. Publishing trends (number of papers) in the area of phosphogypsum research (using Scopus Database). 
There are various directions and ways for the direct use of phosphogypsum and its processing into other products, which have proven technical feasibility and expediency for the use of phosphogypsum in the national economy instead of traditional raw materials.

According to the aforementioned properties of phosphogypsum, the field of research is currently (Figure 2) shifting more towards environmental sciences, but engineering research is simultaneously being actively developed. Research in materials science is also being developed owing to the component composition of phosphogypsum (Figure 3).

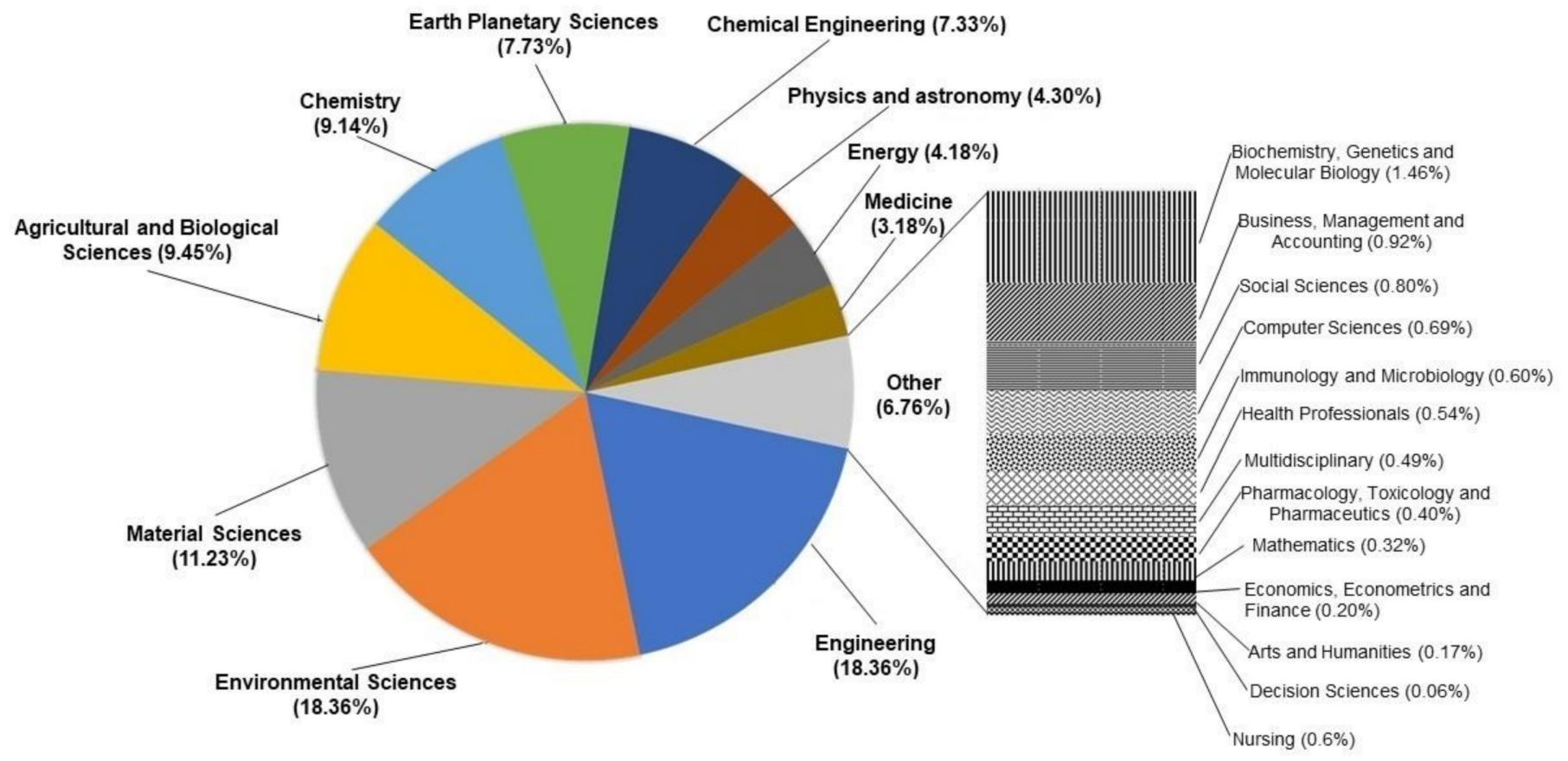

Figure 2. Papers in the field of "phosphogypsum" classified by fields (Scopus Database).

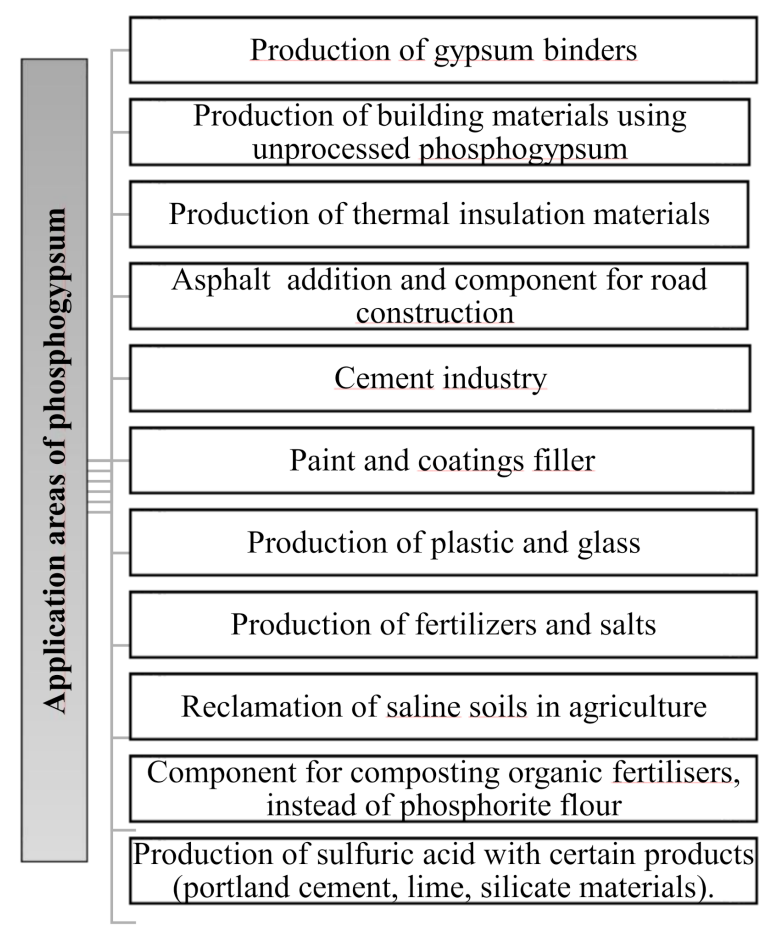

Figure 3. The main directions of phosphogypsum recycling. 
At the same time, the direction of using phosphogypsum in agriculture for fertilization and reclamation of soils, especially saline soils, remains a quite promising direction, owing to the changes in climatic parameters and aridization, with increasing areas of anthropogenic (secondary) saline soils (Figure 3).

Areas of biotechnology and environmental protection where phosphogypsum is not only applied as a substrate, a carrier of bioculture, but at the same time is used as a substrate that has nourishing value when it comes to phosphogypsum application in technologies based on the microorganisms (for example, off-gas cleaning, wastewater treatment, reclamation of soils contaminated with oil-based products/petroleum products, and drilling cuttings) are becoming relevant and increasingly popular.

Development in the field of research on the properties and applications of phosphogypsum is taking place in many countries with different levels of economic development, such as in Western Europe, Africa, India, Russia, and especially in China (Figure 4). The use of phosphogypsum as a secondary raw material is in high demand in many countries of the world. Leadership in terms of published papers belongs to China, as a country where the economy is gaining momentum and the use of cheap secondary resources is a very relevant issue, although countries of America and Europe, as well as India and Russia, are also in a tow.

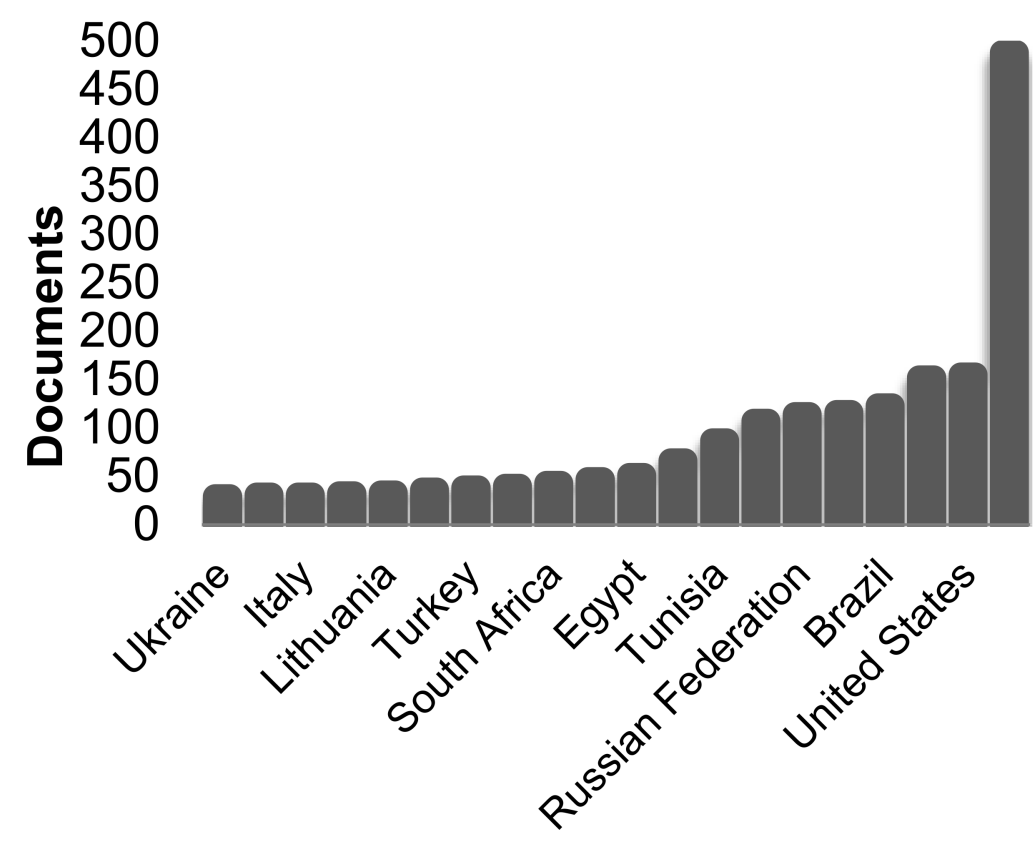

Figure 4. Comparison diagram behind the regions of research on phosphogypsum issues (Scopus Database).

Considering the nature of Ukraine, as a country with an agrarian component and because of the economic situation, the use of phosphogypsum has shifted the emphasis in recent times. The use of phosphogypsum for road construction has been suspended because of the short duration of the roadway covering and the possibility of harmful components of phosphogypsum getting into the environment. In addition, the use of phosphogypsum in the construction materials and cement industry has been slowed down by the economic crisis.

\subsection{Phosphogypsum Recycling in Various Industry Fields}

Theoretically, the construction materials industry's need for gypsum raw materials can be almost fully met by gypsum-containing waste (phosphogypsum). Various technologies for the production of construction and high strength gypsum from phosphogypsum have been developed, but they have not been sufficiently implemented in practice [23-32]. 
The technologies of phosphogypsum utilization entail transforming it into construction materials and products, and several variants of technological operations sequence are applied [33]. In the world, the construction sector accounts for over $40 \%$ of phosphogypsum usage [34].

Phosphogypsum preparation for the production of gypsum binders can be divided into four methods:

- washing of phosphogypsum with water;

- washing in combination with neutralization and deposition of impurities in water suspension;

- the method of thermal decomposition of impurities;

- the introduction of additives that neutralize, mineralize, and regulate crystallization before and after firing.

The first and second methods are associated with the generation of large amounts of contaminated water (2-5 $\mathrm{m}^{3}$ per 1 ton of phosphogypsum) and the high costs of their removal and water treatment [35].

The disadvantages of the implementation of such engineering solution are as follows:

- a complicated method of obtaining a hemihydrate binder that requires high-energy devices used for mechanical and chemical activation of raw materials;

- the need to use fresh phosphogypsum with stable humidity and the difficulty of calculating the required amount of calcium sulfate hemihydrate to ensure the humidity needed for pressing;

- the need for high-energy grinding and the use of superplasticizers, which significantly increases the cost of the binder.

Engineering solutions have been developed for producing a gypsum binder from phosphogypsum, which has been aged for a long time in dumpsites [36]. The main disadvantages of the known technologies of phosphogypsum utilization for the processing into construction materials and products are significant consumption of thermal resources per unit of finished product, the presence of a high amount of gaseous emissions in the environment, and the mandatory process of adding water to wash phosphogypsum from water-soluble impurities. The generation of wastewater in the technological cycle has a negative side effect on the environment and requires additional construction of wastewater treatment facilities.

Thus, the application of phosphogypsum as an additive in cement manufacturing is only possible when phosphogypsum is dried and granulated. The humidity of granulated phosphogypsum should not exceed 10-12\%. Additionally, this technology, besides the high energy consumption, is burdened by the need for large-scale supplies of blast-furnace slag and additional raw materials for cement clinker production [34].

So, the large-scale consumption of phosphogypsum in the cement industry is constrained by the significant content of controlled for raw materials impurities such as water-soluble $\mathrm{P}_{2} \mathrm{O}_{5}$ and fluorine compounds.

The use of phosphogypsum to produce sulfuric acid and Portland cement is similar to the processing of natural anhydrite for these products through the Muller-Kuhne process, commonly used in Austria, South Africa, and Poland [37]. The method regenerates at least $90 \%$ of the sulphuric acid needed to decompose phosphate during the phosphoric acid production. However, this method makes economic sense only when the main method of sulfuric acid production (contact) is ineffective because of the absence or remoteness of traditional sources of sulfur-containing raw materials (elementary sulfur, sulfuric acid, off-gases containing sulfate anhydride).

There is a method of deep processing of phosphogypsum into sulfate acid with subsequent production of ammonium nitrate using ion-exchange technology by gas-liquidphase conversion of gypsum with carbon dioxide and ammonia water [37]. e Malik et al. [37] propose to carry out the regeneration of used ion nitric acid with the production of ammonium nitrate; this requires an additional source of production or input of nitric acid. 
Furthermore, the formed phosphate acid contains impurities of phosphorus pentoxide and can only be used in phosphate fertilizer production processes. Therefore, this method can only be used in complex fertilizer production facilities [1,37].

Rare-earth elements from phosphate raw materials convert up to $90-95 \%$ in to phosphogypsum in the production of phosphorus-containing products, and the degree of their extraction as chlorides is about $95 \%$. Up to $4 \mathrm{~kg}$ of cerium (III) chloride can be produced from 1 ton of phosphogypsum [38].

The important attribute of the old phosphogypsum dumps in Ukraine, originated after processing of Khibiny apatite, is the absence of radioactive elements in the composition, unlike other sources of rare-earth metals. This means that the obtained rare-earth elements are not radioactive and do not require decontamination, which makes their production more profitable. Sulphogypsum or nitric acid treatment methods are used to extract rare-earth elements from phosphogypsum. These methods convert rare-earth elements into solution with further processing with ammonia, alkalis, and fluorides for their extraction [39,40].

Depending on the solution composition, extraction or sedimentation methods are used to remove rare-earth elements [41]. There is a method [42] that involves the leaching of rare-earth metals from phosphogypsum by $1-5 \%$ sulphuric acid solution, sorption of rare-earth metals from the leaching solution by cationite, desorption of rare-earth metals, deposition of rare-earth metal concentrate from desorbate, obtaining rare-earth metal concentrate, and mother liquor used for desorption of rare-earth metals.

Notably, the implementation of such engineering solutions generates significant amounts of wastewater, which also needs further treatment and disposal. The process is energy-intensive and requires significant investments in chemical reagents. At the same time, these methods of rare-earth elements extraction from phosphogypsum do not always allow high results (the level of extraction is variable from 25 to $80 \%$ ). Besides, the described technologies require large volumes of equipment for sulphate acid leaching and filtration equipment.

Despite a large number of studies [41-44], the main drawbacks of the known methods are the low recovery of rare-earth elements from phosphogypsum (30-50\%); the need to use acids with a high concentration ( $40-50 \%)$; and the formation of secondary waste, which requires recycling [43].

The disadvantages of gypsum plasterboard include the following qualities [45]: low water resistance; high hygroscopic; and high creep under load, especially when humidifying, so the products based on gypsum are used in rooms with a relative air humidity of no more than $60 \%$, because, when humidifying, there is a significant decrease in strength and brittleness-gypsum plasterboard sheets cannot be exposed to shock loads, as dents form on them. To eliminate the disadvantages of the gypsum plasterboard, several studies $[45,46]$ have proposed technology on a composite binder containing phosphogypsum and sulfur-containing materials; for instance, as in the study of Zhou et al. [46], where dehydrated phosphogypsum was granulated, pressed, and hydrated with periodic pressing into paperless and fibreless gypsum plasterboards with a flexural strength of $14.7 \mathrm{MPa}$. The researchers were processing phosphogypsum into gypsum plasterboard. However, the main disadvantage of gypsum plasterboard production using phosphogypsum is the presence of various impurities in it, which requires additional operations: neutralization, enrichment, and drying. Such operations increase the cost of products and reduce their competitiveness in the market.

Gong et al. [47] conducted a study on the properties of phosphogypsum in a muffle furnace and found that the solution with calcined phosphogypsum at $800^{\circ} \mathrm{C}$ has characteristics of low density, lightweight, and stable operation [47]. The use of phosphogypsum for cement mortar production improves its mechanical properties. Still, however, the presence of impurities in the feedstock, i.e., phosphogypsum, is important. They influence the ecological and physical-mechanical properties of received materials and their service life. If phosphogypsum has radiation contamination, its use in the cement industry is significantly limited. Accordingly, this technology can be used selectively and only when 
analyzing the properties of particular phosphogypsum, which is locally produced in a particular area.

The use of phosphogypsum for the production of composite materials based on asphaltic binders has been common, as well as in road construction for the construction of road bases and as an additive to asphalt concrete mixtures [34,48-52]. The advantage of such use of phosphogypsum is the following [53]: roads with the use of phosphogypsum are $30 \%$ cheaper than roads with the use of traditional technologies and can be laid in marshy areas. Thus, at the first stage of road construction, it is possible to make the intermediate type, making bases from phosphogypsum, and thereafter laying other constructive layers from rubble and asphalt concrete. At the same time, it should be noted that the results of the experiments carried out by Soldatkin and Hohlov [54] showed that the use of phosphogypsum for road construction can lead to the destruction of roads in areas with high water exchange rates and contamination of soil and groundwater with sulfates [54].

Phosphogypsum in mixtures with other components is mainly used for the construction of road bases [55-57], because phosphogypsum roads without asphalt covering are characterized by mechanical separation of phosphogypsum fragments, which could later lead to contamination of the surrounding area.

However, the results of long-term measurements (more than 5 years) and monitoring of road surface containing phosphogypsum show frequent deformations and leaching out of phosphogypsum components, particularly heavy metals, into the environment. For example, phosphogypsum roads without asphalt pavement are characterized by phosphogypsum mechanical fragment stretching, which could lead to further contamination of the surrounding area $[58,59]$.

\subsection{Phosphogypsum Recycling in Agriculture}

Phosphogypsum contains residues of phosphate, phosphoric acid (up to $4 \%$, including water-soluble form up to $1.5 \%$ ), sesquioxide, silicon compounds, rare-earth elements trace contaminants as impurities [60]. Consequently, phosphogypsum is an ameliorant and a multicomponent fertilizer [61]. On the bacterial complex side, phosphogypsum has a positive effect on the growth of streptomyces and root bacteria. The most common types of bacteria are proteobacteria, acidophilic bacteria, and actinobacteria. These groups account for over $78 \%$ of the total number of microbial groups, followed by Firmicutes and Chloroflexi [62].

Belyuchenko [63] confirms that phosphogypsum does not interfere with plant growth in general. During storage in a dump, the surface of moist phosphogypsum can be covered with lower plants, mainly algae, while the surface of stale phosphogypsum, relatively dry, slowly overgrows with flowering plants [63].

The presence of calcium, phosphorus, and sulphur in phosphogypsum makes the substance beneficial for use as a fertilizer additive in agriculture. The advantage of using phosphogypsum in agriculture is that it does not need to be purified from $\mathrm{P}_{2} \mathrm{O}_{5}$; this impurity plays a positive role in suppressing the impact of fluorine, which is a component of phosphogypsum, and additives can be used to form insoluble compounds in the soil. However, phosphogypsum, as it comes to dump (without neutralization), is not applied to fertile soil because of high acidity, poor physico-chemical, and material handling properties (which are important for the final user).

There is a well-known process of converting phosphogypsum into complex fertilizer [64]. The process involves processing of the initial phosphogypsum by phosphate solution, filtration, and drying of the finished product. The process is carried out commonly in two stages: at the first stage, the pre-calcined phosphogypsum is treated with alkaline carbonate reagent to $\mathrm{pH} 9-10$, and at the second stage, the obtained carbonate pulp is mixed with a semi-product of phosphoric acid production - washing water-to $\mathrm{pH}$ 5.4-6. Thus, the processing of phosphogypsum allows the obtainance of complex KPCaS-mineral fertilizer and dicalcium phosphate. 
Another way of complex conversion of phosphogypsum in fertilizers includes preparation of a solution of ammonium carbonate; conversion of phosphogypsum by ammonium carbonate solution on the reaction of the exchange decomposition of salts: $\mathrm{CaSO}_{4} \cdot 2 \mathrm{H}_{2} \mathrm{O}$ $+\left(\left(\mathrm{NH}_{4}\right)_{2} \mathrm{CO}_{3}\right)$ solution $=\mathrm{CaSO}_{3}+\left(\mathrm{NH}_{4}\right)_{2} \mathrm{SO}_{4}+2 \mathrm{H}_{2} \mathrm{O}$; separation on the filter of the converted suspension into ammonium sulphate solution, which is evaporated to extract crystalline or granulated ammonium sulfate; and carbonate residue mixed with ammonium nitrate alloy, granulated, and dried [65].

However, both methods have several disadvantages: the technological complexity of process and sewage generation, which require neutralization.

In agronomy, phosphogypsum can be effectively used for the reclamation of acidic soils (together with lime), for the reclamation of saline soils, and as fertilizer meliorants (1 ton of phosphogypsum contains about $10 \mathrm{~kg}$ of phosphorites) for composting with biopreparation and organic fertilizers. The use of phosphogypsum for plastering and liming soils may be as effective as natural raw gypsum.

There are known methods for treating manure with phosphogypsum to stop losses of ammonia nitrogen [66] and methods for producing slow-release nitrogen fertilizers from phosphogypsum, such as $\mathrm{CaSO}_{4} \cdot \mathrm{CO}\left(\mathrm{NH}_{2}\right)_{2}$. The advantages of this type of fertilizer are reduction of solubility of carbamide, which reduces washout losses [48]. However, it is necessary to take into account the different characteristics of phosphogypsum depending on the conditions of its formation and the initial raw materials. The impurities it contains may have a negative impact on the quality of the resulting product and its safe use in agriculture. Therefore, it is necessary to consider possible ways of binding toxic components of phosphogypsum.

There are methods of obtaining calcium-phosphoric additive from phosphogypsum by the processing of extraction phosphoric acid, which is used in animal husbandry, as feed dicalcium phosphate (precipitate) [67]. Feed precipitate is a mineral feed for different animal and bird species. It is used in animal husbandry as a veterinary supplement to conventional feed as premixes and compound feeds. The disadvantages of this method are high energy costs of the first stage, the use of productive phosphoric acid, and a high fluorine content in the finished product. Furthermore, as in previous engineering solutions, large amounts of wastewater are generated in the process of treatment, which can lead to secondary pollution of the environment.

In Brazil, major phosphate fertilizer producers generate around 12 million tons of phosphogypsum per year. Brazilian phosphogypsum has been used in agriculture as a soil improver for many years. For its safe long-term use, it is necessary to characterize the impurities present in phosphogypsum and to study the leaching or distribution of such impurities in soil water or other elements of the ecosystem. For this purpose, an experiment was conducted by Saueia et al. [68], in which columns filled with typical Brazilian sandy and clay soils mixed with phosphogypsum were washed with water to gently remove these elements. The results obtained within the study [68] showed that the addition of phosphogypsum to the soil does not significantly increase the number of rare-earth elements in water.

It should be noted that, during any technological processes of phosphogypsum use in agriculture, it is necessary to conduct field studies with accurate calculation of the dosage of phosphogypsum. Moreover, as phosphogypsum may contain different impurities (such as heavy metals) that are toxic to plants, the preliminary treatment is appropriate. It is necessary to consider that repeated application of high doses of phosphogypsum (12$24 \mathrm{t} / \mathrm{ha}$ ) leads to a significant increase of total and water-soluble fluorine content in soil [69]. Besides, the phosphogypsum application in the soil can enhance the vertical and horizontal migration of heavy metals, which must also be considered for dosing. 


\section{Visualization of the Areas of Phosphogypsum Research and Identification of Alternative Solutions for Its Use}

Through the VOSviewer programme, a visualization of cluster interconnections by keyword "phosphogypsum" was carried out in research publications of various fields of phosphogypsum utilization (Figure 5).

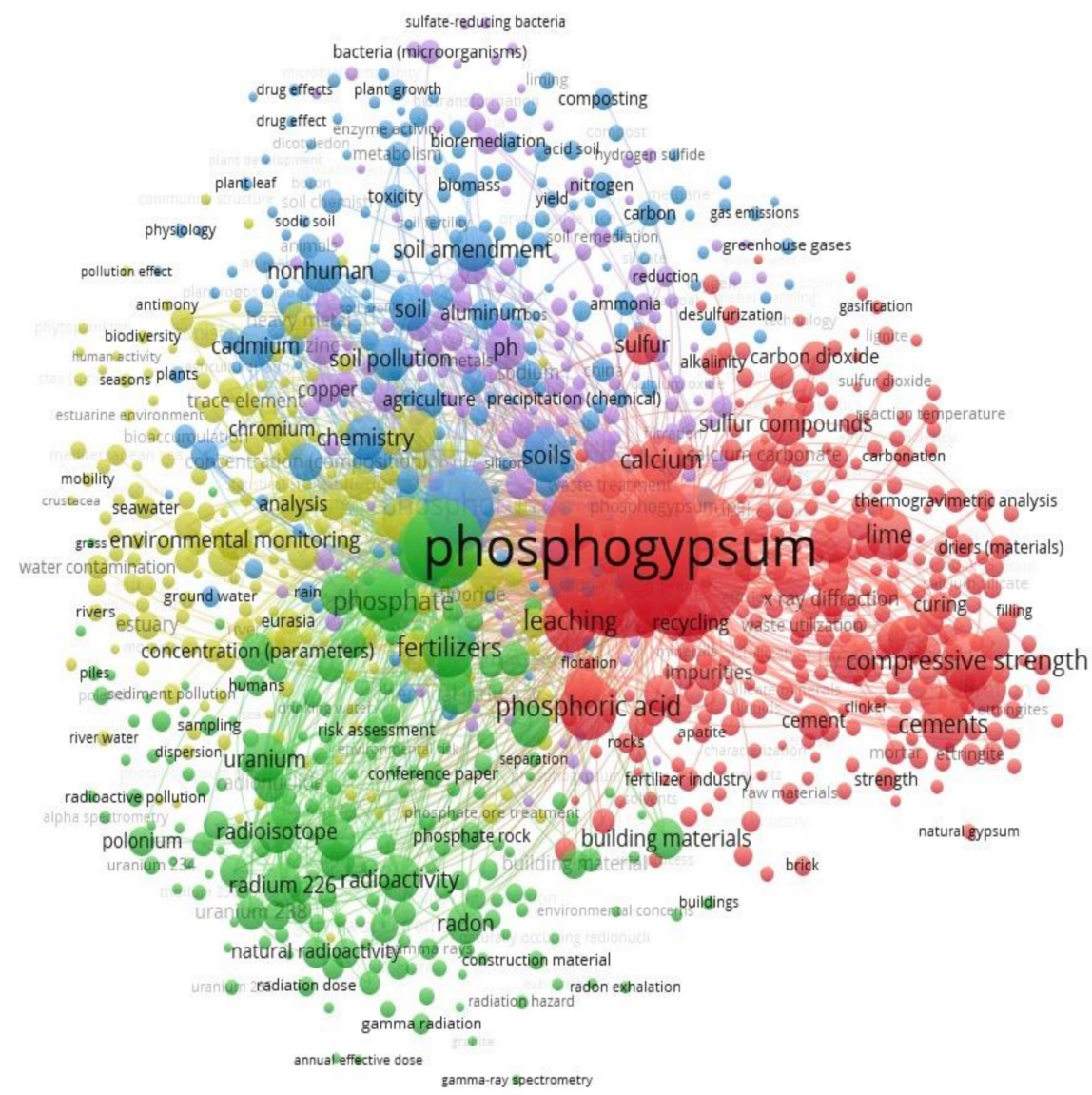

Figure 5. General network visualization (constructed via VOSViewer v.1.6.15): 5 clusters, 94,846 links, 209,564 total link strength.

Five clusters were formed: red cluster-phosphogypsum recycling in the construction industry; green cluster-radiation pollution problem of phosphogypsum and phosphate fertilizers; yellow cluster-monitoring migration of phosphogypsum components in the ecosystem, with the mobile forms of heavy metals and their inflow into aquifers from phosphogypsum dumps; blue cluster-use of phosphogypsum in agriculture as an ameliorant and a component of complex fertilizer; and purple cluster-the impact of phosphogypsum on microorganisms, particularly in bioremediation processes.

The analysis of phosphogypsum component composition is important in assessing the environmental safety of phosphogypsum use (Figure 6). Phosphogypsum of different genesis and storage time has a variation in the composition of impurities, which significantly affects the scope of its possible application. The composition of phosphogypsum is determined by the initial phosphorite raw material from which phosphate fertilizers are produced. 


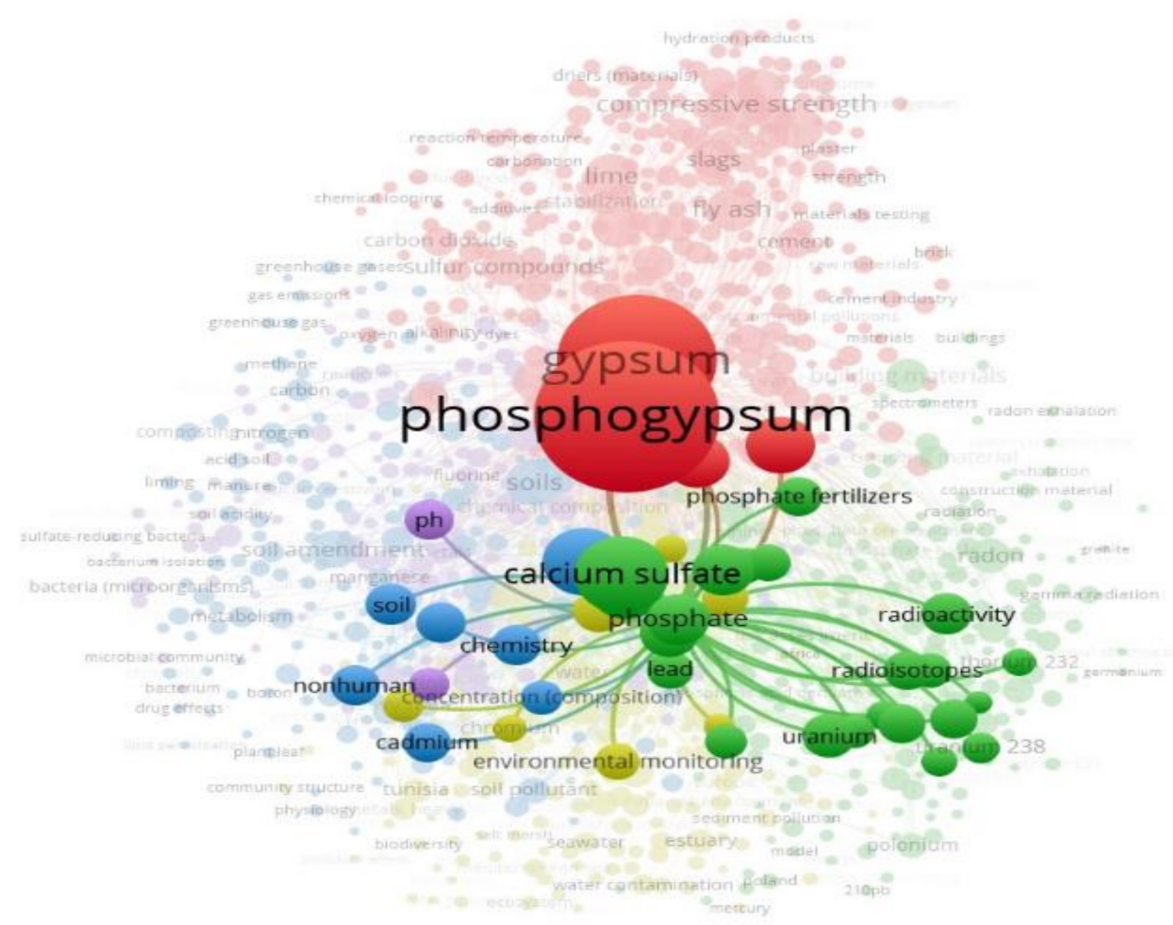

Figure 6. The fragment of overlay visualization (constructed via VOSViewer v.1.6.15).

As can be seen from the highlighted fragment of visualization (Figure 6), the main components that are important for the implementation of certain technological solutions of phosphogypsum conversion are calcium sulfates in a semi-hydrate or dihydrate form, undecomposed residues of phosphates (Table 1), and the potential presence of heavy metals and radionuclides. There is a variation in the content of $\mathrm{CaSO}_{4} 2 \mathrm{H}_{2} \mathrm{O}$ in phosphogypsum, which is associated with the technological process, while in the feedstock (apatite, phosphate rock), $\mathrm{CaSO}_{4} 2 \mathrm{H}_{2} \mathrm{O}$ content is not less than $90 \%$.

Table 1. The chemical composition of phosphogypsum converted to dihydrate depending on the type of raw material (in \%) [20].

\begin{tabular}{cccc}
\hline & \multicolumn{3}{c}{ Origin of Raw Materials } \\
\cline { 2 - 4 } $\begin{array}{c}\text { Phosphogypsum } \\
\text { Sample }\end{array}$ & Phosphorite & Apatite-Phosphorite & Apatite \\
\cline { 2 - 4 } & (Tatarstan) & (South African) & (Colsky Peninsula) \\
\cline { 2 - 4 } & Aktyubinsky & Apatite-Phosphorite & Apatite \\
\hline $\mathrm{CaO}$ & 24.4 & 30.0 & 32.4 \\
\hline $\mathrm{SO}_{3}$ & 34.8 & 39.8 & 46.2 \\
\hline $\mathrm{P}_{2} \mathrm{O}_{5}$ (total) & 1.9 & 6.2 & 1.3 \\
\hline $\mathrm{P}_{2} \mathrm{O}_{5}$ (water soluble) & 1.1 & 3.3 & 0.7 \\
\hline $\mathrm{Fe}_{2} \mathrm{O}_{3}$ & 0.9 & 0.7 & 0.1 \\
\hline $\mathrm{Al}_{2} \mathrm{O}_{3}$ & 0.8 & 0.8 & 0.3 \\
\hline $\mathrm{F}$ & 0.1 & 0.3 & 0.3 \\
\hline Insoluble residue & 21.7 & 4.3 & 0.7 \\
\hline Crystalline water & 15.6 & 17.4 & 18.6 \\
\hline
\end{tabular}

The biggest environmental hazard relates to the inflow of chemical impurities contained in phosphogypsum in the form of water-soluble and volatile compounds. The content of radioactive, rare-earth elements, and heavy metals is in direct proportion to their 
content in phosphate raw materials. Figure 7 shows the spectrum of elemental composition of phosphogypsum taken from the production line obtained by means of $\mathrm{X}$-ray fluorescence analysis. The percentage of samples in fresh phosphogypsum content of Strontium is not less than $11.0 \%$, and that of Yttrium is not less than $1.3 \%$ by weight [70].

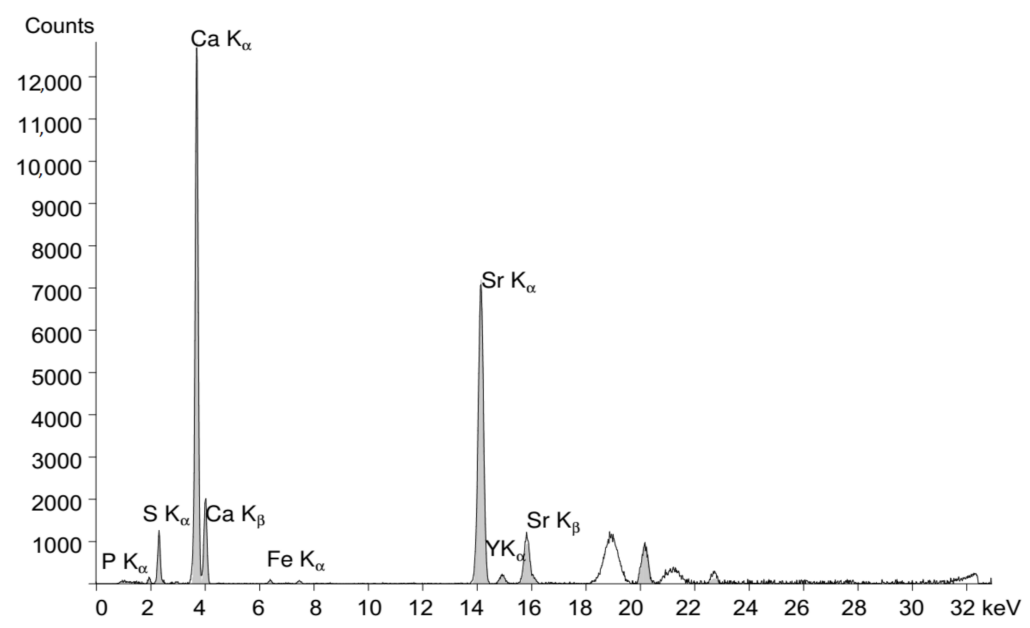

Figure 7. The element spectrum of phosphogypsum sample [70].

Magmatic phosphates (Colsky and South African apatite) have a higher content of rare-earth elements (REEs) than sedimentary phosphates (Morocco, Florida, Senegal, and so on) and cadmium has a lower content of rare-earth elements (REEs) [13,71-73].

The overlay visualization shown in Figure 8 has been chosen as a more effective tool for checking the latest trends in time scale studies. The size of the circles corresponds to the predominance of terms when publishing studies in this area. The distribution of colors depends on the year of publication (average for the cluster); the last ones are yellow. Thus, the most intensive use of terminology for the clusters under study occurred in 2016. The main core clusters are defined by terms that include the main components of phosphogypsum use.

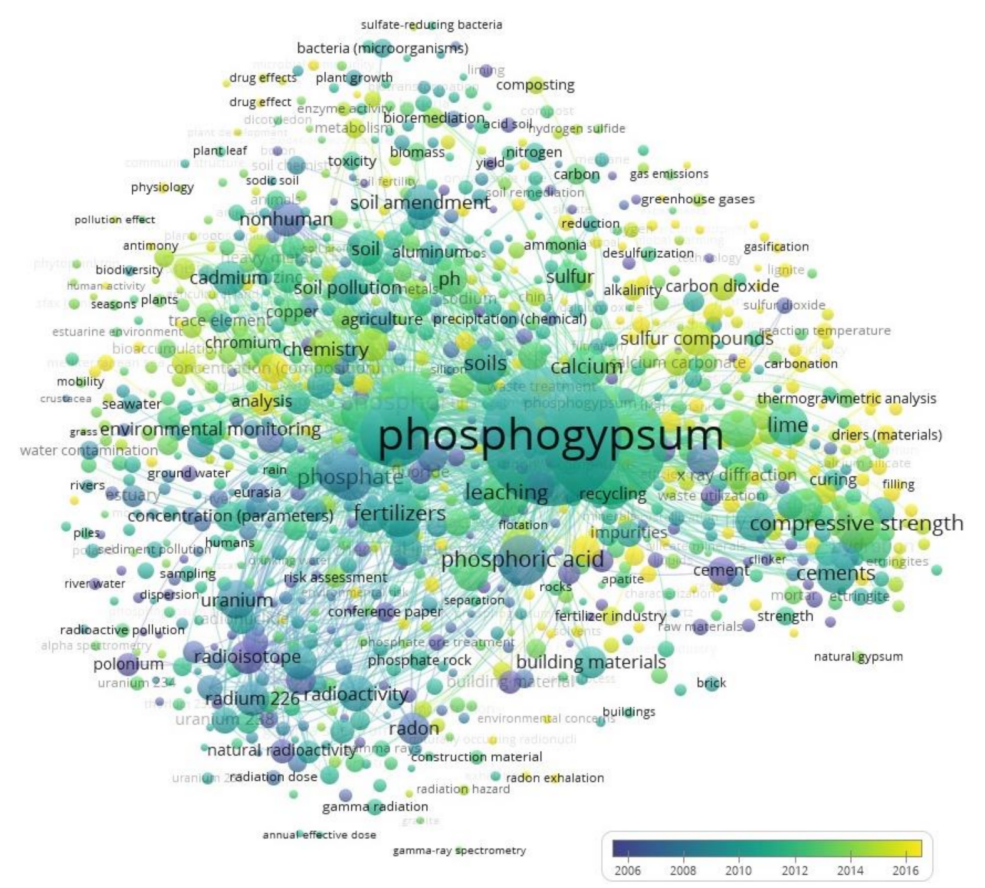

Figure 8. Overlay visualization of most frequent terms (constructed via VOSViewer v.1.6.15), where the score of the item is the time since publication. 
Among the well-known areas of recycling and disposal of phosphogypsum, it is quite new to consider the use of phosphogypsum in environmental protection technologies.

Zhang et al. [74] conducted a study on the development of an energy-efficient methodology of pure calcium carbonate production and the binding of $\mathrm{CO}_{2}$ minerals by hydrolyzate of phosphogypsum decomposition products. Pure calcium carbonate was obtained by extraction and mineralization of $\mathrm{CO}_{2}$ using the hydrolyzate solution of phosphogypsum decomposition products. The carbonization rate of over $90 \%$ was obtained when the absorption of the liquid phase reached saturation. This method can be referred to as an alternative solution to the environmentally friendly use of phosphogypsum [74], which is consistent with the data obtained earlier by Contreras et al. [75].

A study by Bulat et al. [76] substantiates the expediency of creating X-ray protective structures from composite material based on phosphogypsum. However, the influence mechanisms of composite materials based on phosphogypsum binders require further studies in the field on the efficiency of protection against $X$-ray and gamma radiation, which also requires further studies [76].

In several studies $[77,78]$, there was a focus on using phosphogypsum for remediation of contaminated soils (after oil pollution, for remediation of soils contaminated with fuel oil). There is a well-known method for remediation of oil-contaminated soils or soils in the elimination area of oil pollution, characterized by the fact that contaminated soil is not removed, and ameliorants are applied to the soil based on a mixture of phosphogypsum; sand; humus; and mineral fertilizers from nitrogen, phosphorus, and potassium with subsequent ploughing and sowing of crops. It is one of the directions for using phosphogypsum in environmental protection technologies.

A mechanical action (ploughing and application of phosphogypsum) mixes the layers. In this case, soil particles saturated with oil will interact with intact soil particles, reducing the pressure of contamination on the substrate. Further decomposition of the organic component of oil will take place under conditions of acidic reaction preservation. Moreover, the redox potential (RP) will be rebalanced, and the reaction of soil respiration will be restored. Finally, the soil uptake of $\mathrm{CO}_{2}$ and its intoxication will be reduced [77]. Automorphic soils are characterized by high levels of RP $(550-750 \mathrm{mV}$ in podzols, $400-600 \mathrm{mV}$ in chernozems, $350-450 \mathrm{mV}$ in gray soils). Irrigation reduces RP. In hydromorphic soils, RP is subject to strong seasonal fluctuations and, when the soil is moistened, its level is significantly reduced. Values of RP below $200 \mathrm{mV}$ correspond to cutting and restoration conditions in which the processes of transformation take place and restored forms of iron and manganese compounds, sulfites, and nitrites are formed. Accumulation of the latter has a toxic effect on most cultivated plants. Grape plant is highly sensitive to changes in oxidation-reduction conditions and, at RP below $300 \mathrm{mV}$, it suffers from chlorosis.

There is a possibility to use phosphogypsum in the reclamation of drilling cuttings, which are accumulated and stored directly at the drilling site [78,79].

Drilling cuttings are characterized by adverse chemical properties: under wet conditions, they swell and become viscous and sticky, whereas under dry conditions, they are characterized by cohesion and hardness owing to the Na content in the absorbing complex. Drilling cuttings also have high alkalinity, and $\mathrm{pH}$ of 8.68-9.10, which affects plants [79].

For improvement of physical and chemical properties of drilling cuttings, it is necessary to displace the absorbed sodium by calcium; for this purpose, coagulants are used, among which the use of phosphogypsum is very demanded. This is because phosphogypsum, which is a waste product, is much cheaper than gypsum and has higher solubility, and the presence of water-soluble phosphorus in it enhances the reclamation effect $[78,79]$.

It is important to consider the processes of using phosphogypsum with the help of biotechnological methods, which gives grounds to substantiate the possibility of conversion of phosphogypsum components of various groups of microorganisms in environmental protection technologies.

Thus, bioremediation can be used as one of the phosphogypsum management strategies. It is based on the use of living organisms, in particular, microorganisms, to decompose 
or detoxify an environmental pollutant as a safe and inexpensive alternative [80]. Different groups of microorganisms can be involved under these bioprocesses. Thus, the presence of autochthonous microorganisms in the phosphogypsum accumulated in the dump, in particular, bacteria capable of recovering radioactive elements and heavy metals, oxidation, and reduction of sulfates, was determined.

The possibility of using biotechnological methods of drilling wastewater treatment based on biodestruction of organic pollutants was substantiated $[78,79]$. The efficiency of a treatment depends, to a great extent, on the activity of microorganisms-destructors, and the presence of macro- and microelements in the environment. The efficiency of purification depends to a large extent on the activity of microorganisms-destructors, and the presence of macro- and microelements in the environment. A lack of one of the most important elements-phosphorus and calcium - is a limiting factor in the process of drilling wastewater bio-treatment, so the use of phosphogypsum as a cheap source of these elements is promising.

In the study by Barakhnina et al. [81], it was found that, during three days of cultivation in the experiment with the addition of $1.0 \% \mathrm{wt}$. of phosphogypsum, the degree of destruction of carboxymethyl cellulose and polyacrylamide in drilling wastewater was $66.8 \%$ higher than in the control, as $99.8 \%$ [81]. However, this method requires further development and improvement as the implementation on an industrial scale requires activation of the biological component of the process considering all physical and chemical properties of biodegradable material. Another area of phosphogypsum use is its application in biotechnological processes of sewage sludge neutralization. The paper by Chernysh, 2014, describes a method of sewage sludge treatment in systems of anaerobic fermentation with heavy metals deposition into complex sulfide fraction with the help of biogenic hydrogen sulfide-a product of life activity of sulfate reducers, where phosphogypsum is a mineral additive for intensification of bacterial culture development [82]. At the same time, for intensification of bacterial culture development, it would be appropriate to use the process of its bacteria immobilization on a mineral carrier to reduce biomass export from a bioreactor and to transfer the process of treatment into a continuous one, which would increase the productivity of the bioreactor.

Therefore, anaerobic fermentation with sulfate reduction process is a promising alternative for phosphogypsum utilization. It was investigated during our study [83] and confirmed in the study by Zouch et al. [84], where strong sulfide formation was observed from enrichment culture inhabited by marine sediments collected near the wastewater discharge point of the Tunisian fertilizer plant (Sfax, Tunisia). The authors [84] confirmed that Desulphovibrio species are potential candidates for phosphogypsum bioremediation by immobilization of metals and metalloids through sulfide production, which has also been studied in our work [85].

In accordance with our previous studies [20,85], the biotechnologies of processing of complex organic substances allow in anaerobic as well as in aerobic conditions to carry out the decomposition of organic wastes with the formation of volatile fatty acids and carbon dioxide, which, in the liquid phase, is represented by carbon dioxide. The development of the biochemical process of converting phosphate raw materials into phosphate fertilizers is a promising field of study.

The way of the combination of recycling areas of already accumulated phosphogypsum and implementation of new technological solutions for processing phosphorus raw materials will reduce the level of technogenic impact from phosphogypsum on the environment. Therefore, we have formed a model reflecting an integrated approach to environmentally friendly production and recycling of phosphogypsum (Figure 9).

It is important to note that the application of complex compost based on mixing phosphogypsum, elementary superphosphate, manure, and plant residues in the reclaimed soil can reduce the content of mobile forms of heavy metals $(\mathrm{Co}, \mathrm{Mn}, \mathrm{Cu}, \mathrm{Ni}, \mathrm{Pb})$ by $60-70 \%$ or more per year owing to the transformation of heavy metals into forms of organic complexes and metal salts that are hardly accessible to plants [86]. Phosphogypsum 
can be considered as an acid-resistant mineral carrier, which is additionally a source of macro- and trace elements for the growth process of the necessary ecological and trophic groups of bacteria. As an immobilizing carrier, phosphogypsum with a modified surface is characterized by low porosity; at the same time, a stable biofilm is formed on the surface of the granules. So, phosphogypsum is also promising to be used as an immobilization carrier for bacteria in bioreactors.

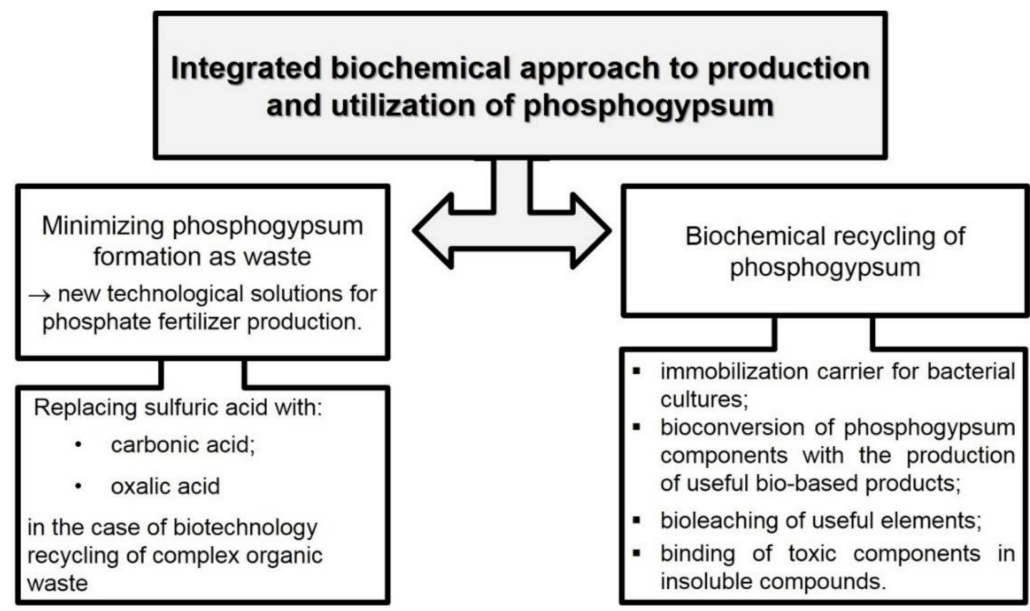

Figure 9. An integrated biochemical approach to production and utilization of phosphogypsum.

\section{Conclusions}

The problem of formation, storage, and actual disposal of phosphogypsum dumps accumulated in the environment remains unsolved today. Existing dumps cause pollution of the atmosphere, groundwater, soil, and vegetation of adjacent areas, causing alienation of soils from existing ecosystems and affecting the adjacent areas, including agricultural purposes. At the same time, these wastes still have useful physical, chemical, and biochemical properties, which makes it possible to expand the scope of their environmentally safe application. Therefore, in this study, trends in the management of this waste were considered and analyzed. Through the VOSviewer program, a visualization of cluster interconnections by keyword "phosphogypsum" was carried out in research publications of various fields of phosphogypsum utilization and its application in industry. It should be noted that the process of valorization of phosphogypsum has an important influence on its component composition and effective extraction of useful components and binding of toxic ones during phosphogypsum processing.

Thus, based on the analysis of current research on phosphogypsum, we have determined that the components of its structure allow the most efficient use of phosphogypsum. Therefore, the concept of an integrated biochemical approach to phosphogypsum management issues was determined. In the context of the proposed concept, the use of various bioprocesses of phosphogypsum recovery from existing waste dumps and implementation of new biotechnological solutions for processing phosphorus raw materials are presented, which will reduce the level of technogenic pressure on the environment.

Further studies will be aimed at the experimental study of the possibility to use phosphogypsum as a mineral carrier for beneficial groups of microorganisms in bioprocesses of detoxification of environmental components.

Author Contributions: Conceptualization, methodology, project administration, and writingoriginal draft preparation, Y.C.; software and formal analysis, O.Y. and V.C.; conceptualization, validation, writing - review and editing, and funding acquisition, H.R. All authors have read and agreed to the published version of the manuscript.

Funding: The research is carried out as planned research projects of the Department of Ecology and Environmental Protection Technologies, Sumy State University according to the scientific and technical program of the Ministry of Education and Science of Ukraine (state registration № 0116U006606) 
(Y.C.). Furthermore, this research was funded by the Internal Grant Agency of the Faculty of Tropical AgriSciences, Czech University of Life Sciences, Prague, grant no. 20205008 (H.R.).

Institutional Review Board Statement: Not applicable.

Informed Consent Statement: Not applicable.

Data Availability Statement: Not applicable.

Acknowledgments: We are thankful to the Czech government support provided by the Ministry of Foreign Affairs of the Czech Republic, which allowed this scientific cooperation to start within the project "AgriSciences Platform for Scientific Enhancement of HEIs in Ukraine".

Conflicts of Interest: The authors declare no conflict of interest.

\section{References}

1. Malik, N.Y.; Malovanyi, M.S.; Malyk, O.V. Two-Stage chemical processing of phosphogypsum into ammonium nitrate. Chem. Technol. Subst. Appl. 2005, 536, 207-211. (In Ukrainian)

2. Malanchuk, Z.R.; Vasylchuk, O.Y.; Okseniuk, R.R. Current trends of technogenic phosphogypsum fields use and recycling. Bull. NUWEE Tech. Sci. 2016, 2, 133-139. (In Ukrainian)

3. The State Department of Agro-Industrial Development, Environment Protection and Natural Resources in Vinnytsia Region. The Report on the State of the Environment in Vinnytsia Region, 2018 Year; The State Department of Agro-Industrial Development, Environment Protection and Natural Resources in Vinnytsia Region: Vinnytsia, Ukraine, 2019. (In Ukrainian)

4. Florida Industrial and Phosphate Research Institute. Potential Phosphogypsum Uses; Florida Industrial and Phosphate Research Institute: Bartow, FL, USA, 2020. Available online: http:/ / www.fipr.state.fl.us/about-us/phosphate-primer/potentialphosphogypsum-use/ (accessed on 29 July 2020).

5. Chuan, L.M.; Zheng, H.G.; Zhao, J.J.; Wang, A.L.; Sun, S.F. Phosphogypsum production and utilization in China. IOP Conf. Ser. Mater. Sci. Eng. 2018, 382, 022099. [CrossRef]

6. Kulczycka, J.; Kowalski, Z.; Smol, M.; Wirth, H. Evaluation of the recovery of rare earth elements (REE) from phosphogypsum Waste-Case study of the WIZÓW Chemical Plant (Poland). J. Clean. Prod. 2016, 113, 345-354. [CrossRef]

7. Manzhina, S.A.; Denisov, V.V.; Denisova, I.A. Usingof large-scale waste phosphogypsum to reduce emis-sions of $\mathrm{SO}_{2}$-containing coal power plant. Eng. J. Don 2014, 28, 77-87. (In Russian)

8. El Kateb, A.; Stalder, C.; Rüggeberg, A.; Neururer, C.; Spangenberg, J.E.; Spezzaferri, S. Impact of industrial phosphate waste discharge on the marine environment in the Gulf of Gabes (Tunisia). PLoS ONE 2018, 13, e0197731. [CrossRef] [PubMed]

9. Gaudry, A.; Zeroual, S.; Gaie-Levrel, F.; Moskura, M.; Boujrhal, F.-Z.; El Moursil, R.C.; Guessous, A.; Mouradi, T.; Givernaud, T.; Delmas, R. Heavy metals pollution of the Atlantic marine environment by the Moroccan phosphate industry, as observed through their bioaccumulation in Ulva lactuca. Water Air Soil Pollut. 2007, 178, 267-285. [CrossRef]

10. El Zrelli, R.; Rabaoui, L.; Abda, H.; Daghbouj, N.; Perez-Lopez, R.; Castet, S.; Aigouy, T.; Bejaoui, N.; Courjault-Rade, P. Characterization of the role of phosphogypsum foam in the transport of metals and radionuclides in the Southern Mediterranean Sea. J. Hazard. Mater. 2019, 363, 258-267. [CrossRef] [PubMed]

11. Kutepova, N.A.; Korobanova, T.N. Features of deformation development in phosphogypsum dumps near the Balakovo town in the Saratov region. Min. Inf. Anal. Bull. 2017, 10, 132-140. (In Russian) [CrossRef]

12. Villa, M.; Mosqueda, F.; Hurtado, S.; Mantero, J.; Manjon, G.; Perianez, R.; Vaca, F.; Garcia-Tenorio, R. Contamination and restoration of an estuary affected by phosphogypsum releases. Sci. Total Environ. 2009, 408, 69-77. [CrossRef] [PubMed]

13. Nadymova, M.A. A patite concentrate as a promising source of rare-earth metals in complex processing. In "The North and the Arctic in the New Global Development Paradigm. Luzin Readings", Proceedings of the International Scientific and Practical Conference, Apatity, Russia, 14-16 April 2016; Luzin Institute for Economic Studies: Saint Petersburg, Russia, 2016; pp. 674-679. (In Russian)

14. Tovazhnyansky, L.L.; Meshalkin, V.P.; Kapustenko, P.O.; Bukhkalo, S.I.; Arsenyeva, O.P.; Perevertaylenko, O.Y. Energy efficiency of complex technologies of phosphogypsum conversion. Theor. Found. Chem. Eng. 2013, 3, 225-230. [CrossRef]

15. Petrenko, D.V. Effect of Phosphate Fertilizer on the Strontium Content of the Landscapes. Ph.D. Dissertation, Kuban State Agrarian University, Moscow, Russia, 2014. (In Russian)

16. Torres-Sanchez, R.; Sanchez-Rodas, D.; Sanchez de la Campa, A.M.; de la Rosa, J.D. Hydrogen fluoride concentrations in ambient air of an urban area based on the emissions of a major phosphogypsum deposit (SW, Europe). Sci. Total Environ. 2020, 714, 136891. [CrossRef] [PubMed]

17. Kasimov, A.M.; Leonova, O.E.; Kononov, Y.A. Utilization of phosphogypsum with available materials for the production of gypsum binders. In Cooperation in Solving Waste Problems, Proceedings of the 4th International Conference, Kharkov, Ukraine, 31 January-1 February 2007; EcoInform: Kharkov, Ukraine, 2007; pp. 120-122. (In Russian)

18. Sharipov, T.V. Processing Karate Phosphorites into Sodium Hexafluorosilicate. Dissertation, Bashkir State University, Kazan, Russia, 2014. (In Russian)

19. Donskikh, I.V. The influence of fluorine and its compounds on people's health (literature review). Acta Biomed. Sci. 2013, 3, 179-185. (In Russian) 
20. Chernysh, Y.; Plyatsuk, L. Environmentally friendly concept of phosphogypsum recycling on the basis of the biotechnological approach. In International Business, Trade and Institutional Sustainability; World Sustainability Series; Leal Filho, W., Borges de Brito, P., Frankenberger, F., Eds.; Springer: Cham, Switzerland, 2020; pp. 167-182.

21. Yunusova, S.S. Composite Wall Materials and Products Based on Phosphogypsum, Obtained by Semi-Dry Pressing. Dissertation, Samara State Architecture Academy, Samara, Russia, 2004. (In Russian)

22. Maazoun, H.; Bouassida, M. Phosphogypsum management perspectives. Massive valorization or massive storage? ACTA Sci. Agric. 2019, 8, 184-189. [CrossRef]

23. Dvorkin, L.Y.; Shestakov, V.L.; Myronenko, A.V. A Method for Producing Binding Material of Phosphogypsum-Dihydrate. Ukraine Patent UA4226U, 17 January 2005.

24. Dvorkin, L.Y.; Myronenko, A.V.; Shestakov, V.L.; Hryb, Y.S.; Vovk, O.O.; Karpenko, H.V. Method for Preparation of Phosphogypsum Binding Material. Ukraine Patent UA28055U, 26 November 2007. (In Ukrainian)

25. Dvorkin, L.Y.; Shestakov, V.L.; Ischuk, O.O.; Hryb, Y.S.; Vovk, O.O.; Karpovets, V.P. Method for Manufacturing of Phosphogypsum Binding Agent. Ukraine Patent UA32645U, 26 May 2008. (In Ukrainian)

26. Dvorkin, L.Y.; Zhytkovskyi, V.V.; Marchuk, V.V. Method for the Production of Gypsum Articles of Phosphogypsum. Ukraine Patent UA102561U, 10 November 2005. (In Ukrainian)

27. Ivashchenko, Yu.G.; Evstigneev, S.A.; Strakhov, A.V. Obtaining a composite binder based on technogenic raw materials. Sci. Rev. 2015, 8, 177-180. (In Russian)

28. Karpovych, E.O.; Vakal, S.V.; Zolotariov, O.Y.; Sharapov, S.V.; Sokolovych, S.O. Process for the Preparation of Gypsum Binder from Phosphogypsum. Ukraine Patent UA36150U, 10 October 2008. (In Ukrainian)

29. Marakhovska, O.Y.; Pavlenko, O.V.; Vaziiev, Y.H.; Akulenko, V.L.; Pepeliaev, I.O. Process for Processing of Phosphogypsum to Gypsum Binder. Ukraine Patent UA68540U, 26 March 2012. (In Ukrainian)

30. Shepliakov, Y.O.; Movsesian, V.A.; Titkov, A.B.; Shepliakov, O.Y. Method for Manufacture of Construction Articles of Phosphogypsum. Ukraine Patent UA29230U, 10 January 2008. (In Ukrainian)

31. Vinnychenko, V.I.; Ivaschenko, T.H. Process for Phosphogypsum Treatment to the Gypsum Binder. Ukraine Patent UA39919U, 25 March 2009. (In Ukrainian)

32. Vinnichenko, V.I.; Krot, O.Y.; Supryaga, N.M.; Supryaga, D.V. A Method of Manufacturing Construction Products from Phosphogypsum. Ukraine Patent UA112942C2, 10 November 2006. (In Ukrainian)

33. Ivashchenko, T.G.; Ince, D. Ecological aspects of phosphogypsum utilization technologies. Visnyk ChSTU 2014, 2, 223-228. (In Russian)

34. Trunova, I.A.; Sidorenko, R.V.; Vakal, S.V. Analysis of the main directions of a phosphogypsum utilization-a waste of phosphoric acid production. Environ. Saf. 2010, 2, 31-35. (In Russian)

35. Dvorkin, L.I.; Dvorkin, O.I. Building Materials from Industrial Wastes; Phoenix: Rostov-on-Don, Russia, 2007. (In Russian)

36. Derevyanko, V.N.; Tel'yanov, V.A. Technologies for the production of gypsum binders from phosphogypsum. Bull. PSACEA 2010, 2-3, 68-73. (In Russian)

37. Malik, N.Y.; Malovanyi, M.S.; Malyk, O.V. Environmental safety achievements of deep conversion of phosphogypsum into sulfuric acid and ammonium nitrate. Newsl. LNPU 2004, 497, 122-124. (In Ukrainian)

38. Tovazhnyansky, L.L.; Kapustenko, P.L.; Khavin, G.L. Complex processing of phosphogypsum with the extraction of rare earth elements. Integr. Ind. Technol. 2008, 2, 73-81. (In Russian)

39. Lokshin, E.P.; Kalinnikov, V.T.; Ivlev, K.G.; Levin, B.V.; Pogrebnjak, O.S. Method of Recovering Rare-Earth Elements from Phosphogypsum. Russian. Federation Patent RU2293781C1, 20 February 2007. (In Russian)

40. Lokshin, E.P.; Tareeva, O.A.; Kalinnikov, V.T. Method of Phosphogypsum Processing for Manufacture of Concentrate of Rare-Earth Elements and Gypsum. Russian Federation Patent RU2458999C1, 20 August 2012. (In Russian)

41. Vlasian, S.V.; Voloshyn, M.D.; Shestozub, A.B.; Mukhachev, A.P. Process for the Extraction of Rare-Earth Elements from Phosphogypsum. Ukraine Patent UA88658U, 25 March 2014. (In Ukrainian)

42. Fokin, K.S.; Nesterova, E.O. Method of Extracting Rare-Earth Metals from Phosphogypsum. Russian Patent RU2491362C1, 27 August 2013. (In Russian)

43. Bashlykova, T.V.; Zhivaeva, A.D.; Ashirbaeva, E.A.; Danil'chenko, L.M. Method of Processing Phosphogypsum with Extraction of Rare-Earth Elements and Phosphorus. Russian Patent RU2457267C2, 27 July 2012. (In Russian)

44. Zyk, V.V. Method for Extracting Rare Earth Elements from Phosphogypsum. Belarus Patent BY6905C1, 30 March 2005. (In Russian)

45. Markov, S.G. Material-Energy-Saving technology of drywall production. Innov. Sci. 2015, 11, 245-247. (In Russian)

46. Zhou, J.; Li, X.; Zhao, Y.; Shu, Z.; Wang, Y.; Zhang, Y.; Shen, X. Preparation of paper-free and fiber-free plasterboard with high strength using phosphogypsum. Constr. Build. Mater. 2020, 243, 118091. [CrossRef]

47. Gong, X.; Liu, J.; Sun, Z.; Li, F. Effects of phosphogypsum and calcined phosphogypsum content on the basic physical and mechanical properties of Portland cement mortar. J. Test. Eval. 2020, 48, 3539-3549. [CrossRef]

48. Borosenko, J.G.; Jashin, S.O.; Soldatov, A.A. Asphalt Mineral Mixture. Russian Patent RU2436819C1, 20 December 2001. (In Russian)

49. Degirmenci, N.; Okucu, A.; Turabi, A. Application of phosphogypsum in soil stabilization. Build. Environ. 2007, 42, 3393-3398. [CrossRef] 
50. Kasimov, A.M.; Reshta, E.E. Promising treatment processes and waste disposal of certain production of mineral fertilizers. East Eur. J. Enterp. Technol. 2011, 52, 66-70. (In Russian)

51. Kraynyuk, O.V. Construction of Highways with Safe Use of Phosphogypsum and Ash Slag from Thermal Power Plants. Dissertation, Kharkiv National Automobile and Highway University, Kharkiv, Ukraine, 2004. (In Ukrainian)

52. Amrani, M.; Taha, Y.; Kchikach, A.; Benzaazoua, M.; Hakkou, R. Phosphogypsum recycling: New horizons for a more sustainable road material application. J. Build. Eng. 2020, 30, 101267. [CrossRef]

53. Kochetkov, A.V.; Shchegoleva, N.V.; Korotkovskiy, S.A.; Talalai, V.V.; Vasilyev, Y.E.; Shashkov, I.G. The device layers and transport facilities of hemihydrate phosphogypsum (waste byproduct of the production of nitrogen-phosphorus fertilizers). Russ. J. Transp. Eng. 2019, 1, 18SATS119, In Russian. [CrossRef]

54. Soldatkin, S.I.; Hohlov, A.E. Problems of using phosphogypsum in road constrcation. Nedra Povolz'a Prikaspia 2019, 97, 58-61. (In Russian)

55. Folek, S.; Walawska, B.; Wilczek, B.; Miśkiewicz, J. Use of phosphogypsum in road construction. Pol. J. Chem. Technol. 2011, 13, 18-22. [CrossRef]

56. Shen, W.; Zhou, M.; Ma, W.; Hu, J.; Cai, Z. Investigation on the application of steel slag-fly ash-phosphogypsum solidified material as road base material. J. Hazard. Mater. 2009, 164, 99-104. [CrossRef] [PubMed]

57. Cichy, B.; Kraszewski, C.; Rafalski, L. Geotechnical properties of phosphogypsum and its use in road engineering. In Springer Series in Geomechanics and Geoengineering, Proceedings of China-Europe Conference on Geotechnical Engineering; Vienna, Austria, 13-16 August 2016; Wu, W., Yu, H.S., Eds.; Springer: Cham, Germany, 2018; pp. 1664-1667.

58. Kraynyuk, O.; Buts, Y.; Kobzin, V. To question of danger of wastes of industry in building of highways. Constr. Mater. Sci. Mech. Eng. 2013, 71, 153-157. (In Ukrainian)

59. Lyubimova, I.; Tersin, V.; Troshin, M.; Gorobets, V.; Bogomolova, I. Assessing the impact of road construction using phosphogypsum on soil pollution. Dokuchaev Soil Bull. 2009, 63, 75-83. (In Russian)

60. Belyuchenko, I.S.; Dobrydnev, E.P.; Muravev, E.I. Ecological features of phosphogypsum and appropriateness of its use in agriculture. In Proceedings of the II All-Russian Scientific Conference "Problems of Reclamation of Household, Industrial and Agricultural Production Wastes", Krasnodar, Russia, 18-19 March 2010; pp. 13-22. (In Russian)

61. Sheudghen, A.H.; Bondareva, T.N. Use of neutralized phosphogypsum as multicomponent fertilizer for rice crops. Sci. J. KubSAU 2015, 113, 1-27. (In Russian)

62. Zielinska, S.; Radkowski, S. First insight into microbial community composition in a phosphogypsum waste heap soil. Acta Biochim. Pol. 2017, 4, 693-698. [CrossRef]

63. Belyuchenko, I.S. Features of mineral waste and expediency of their use in the formation of complex composts. Sci. J. Kuban SAU 2014, 101, 1-21. (In Russian)

64. Astrelin, I.M.; Krymets, H.V.; Fedorov, O.S.; Moliuha, A.I. Method of Phosphogypsum Processing in Complex Fertilizers with Production Semi Wet-Process Phosphoric Acid. Ukraine Patent UA93253U, 25 September 2014. (In Ukrainian)

65. Erayzer, L.M.; Udovenko, O.H.; Smalii, M.I.; Horniev, V.O. A Method for the Complex Reprocessing Phosphogypsum into Fertilizers. Ukraine Patent UA75743C2, 15 May 2006. (In Ukrainian)

66. Avramchuk, P.P. A method for Treatment of Manure with Phosphogypsum. Ukraine Patent UA32564C2, 15 March 2001. (In Ukrainian)

67. Dmitrevsky, B.A.; Dremov, A.V.; Ivanova, N.Y.; Nifontova, T.K.; Treushchenko, N.N.; Yurieva, V.I. The Method of Obtaining Fodder Dicalcium Phosphate. Russian Patent RU2149828C1, 27 May 2000. (In Russian)

68. Saueia, C.H.R.; Nisti, M.B.; Silva, P.S.C.D.; Oliveira, J.P.D.; Mazzilli, B.P. Lixiviation of rare earth elements in tropical soils amended with phosphogypsum. Int. J. Environ. Anal. Chem. 2019, 6, 675-685. [CrossRef]

69. Trigub, V. Modern processes of migration and accumulation of fluorine in agrolandscapes of irrigation areas. ONU Geogr. Geol. 2009, 14, 362-368. (In Ukrainian)

70. Plyatsuk, L.; Balintova, M.; Chernysh, Y.; Ablieieva, I.; Ablieiev, O. The process of environmentally safe biochemical recycling of phosphogypsum. In Advances in Design, Simulation and Manufacturing. DSMIE 2019, LNME; Lecture Notes in Mechanical Engineering; Springer: Cham, Switzerland, 2020; pp. 843-852.

71. Myrzakhmetov, B.; Sholak, A. Chemical composition and complex processing method of phosphogypsum. In Modern Trends in the Development of Science and Production, Proceedings of the West Siberian Scientific Center Conference: Kemerovo, Russia, 15-16 January 2015; pp. 67-71. (In Russian)

72. Vorobiev, A.E.; Danilova, E.V. Audit of rare-earth apatite ore processing technology. RUDN J. Eng. Res. 2013, 4, 36-40. (In Russian)

73. Samonov, A.E.; Vanshin, Y.V. Problems with apatite processing. Geol. Geogr. Glob. Energy Sci. Tech. J. 2007, 2, 7-9. (In Russian)

74. Zhang, W.; Zhang, F.; Ma, L.; Ning, P.; Yang, J.; Wei, Y. An efficient methodology to use hydrolysate of phosphogypsum decomposition products for $\mathrm{CO}_{2}$ mineral sequestration and calcium carbonate production. J. Clean. Prod. 2020, $259,120826$. [CrossRef]

75. Contreras, M.; Pérez-López, R.; Gázquez, M.J.; Morales-Flórez, V.; Santose, A.; Esquivias, L.; Bolívar, J.P. Fractionation and fluxes of metals and radionuclides during the recycling process of phosphogypsum wastes applied to mineral $\mathrm{CO}_{2}$ seques-tration. Waste Manag. 2015, 45, 412-419. [CrossRef] 
76. Bulat, A.F.; Ivanov, V.A.; Holov, K.S.; Mysovets, Y.V. Radio-Protective properties of phosphogypsum binding agent with rare-earth filler. Sci. Bull. Natl. Min. Univ. 2010, 5, 48-51. (In Ukrainian)

77. Belyuchenko, I.S.; Dobrydnev, E.P.; Muravev, E.I.; Melnik, O.A.; Slavgorodskaya, D.A.; Tereshhenko, E.V. Use of phosphogypsum for reclamation of oil-polluted soils. Work. Kuban SAU 2008, 3, 72-77. (In Russian)

78. Skipin, L.N.; Khramtsov, N.V.; Guzeeva, S.A.; Petukhova, V.S. Possibility of reclamation of drill cuttings and solonetzic soils using phosphogypsum. Agrar. Vestn. Ural. 2013, 6, 71-73. (In Russian)

79. Kalinina, O.V. Application of phosphogypsum for reclamation of mazut-polluted soils. North Cauc. Ecol. Her. 2009, 5, 86-87. (In Russian)

80. Trifi, H.; Najjari, A.; Achouak, W.; Barakat, M.; Ghedira, K.; Mrad, F.; Saidi, M.; Sghaier, H. Metataxonomics of Tunisian phosphogypsum based onfive bioinformaticspipelines: Insights for bioremediation. Genomics 2020, 112, 981-989. [CrossRef]

81. Barakhnina, V.B.; Khafizova, A.A.; Kireev, I.R. The investigation of using of phosphogypsum in drilling discharged waters biopurification. Bashkir Chem. J. 2011, 18, 90-92. (In Russian)

82. Chernysh, Y.Y. Sewage Sludge Utilization by Sulfidogenic Association of Microorganisms. Ph.D. Dissertation, Sumy State University, Sumy, Ukraine, 2014. (In Ukrainian)

83. Plyatsuk, L.D.; Chernish, Y.Y. Intensification of the anaerobic microbiological degradation of sewage sludge under bio-sulfidogenic conditions. J. Solid Waste Technol. Manag. 2014, 40, 10-23. [CrossRef]

84. Zouch, H.; Karray, F.; Armougom, F.; Chifflet, S.; Hirschler-Réa, A.; Kharrat, H.; Kamoun, L.; Hania, W.B.; Ollivier, B.; Sayadi, S.; et al. Microbial diversity in sulfate-reducing marine sediment enrichment cultures associated with anaerobic biotransformation of coastal stockpiled phosphogypsum (Sfax, Tunisia). Front. Microbiol. 2017, 8, 1583. [CrossRef] [PubMed]

85. Plyatsuk, L.D.; Chernysh, Y.Y. The removal of hydrogen sulfide in the biodesulfurization system using granulated phosphogypsum. Eurasian Chem. Technol. J. 2016, 18, 47-54. [CrossRef]

86. Denzanov, G.A.; Petruk, G.D. Resource-Saving technology of bioconversion of natural phosphates. Environ. Bull. 2006, 2, 25. (In Ukrainian) 